\author{
Yernazar Kumar \\ Institute of Diplomacy at the Academy of Public Administration under the President \\ of the Republic of Kazakhstan, Nur-Sultan \\ e-mail: yernazar.kumar@alumni.nu.edu.kz

\section{DE-RADICALIZING THE YOUTH IN KYRGYZSTAN VIA SOCIAL MEDIA AND ITS IMPLICATIONS FOR CENTRAL ASIA}

This paper analyzes the role of social media in fighting radical extremism in Kyrgyzstan by looking at the pilot project conducted by Search for Common Ground Organization that was initiated from 2016 to 2017. The pilot project was aimed at the youth population in order to raise the awareness for issues of radical recruitment risks and create a social media platform for public discourses about radicalism problems. Firstly, the paper introduced the sources and reasons for the emergence of radicalism problems in Kyrgyzstan and Central Asia after the collapse of the Soviet Union. Here, the triangular rise of nationalism, religious ignorance and secularist beliefs were discussed alongside the erosion of education system and the issue of ideological vacuum. All this resulted eventually in the social marginalization of the youth and the society overall. Secondly, we analyzed the reasons of why terrorists and radical movements targeted the youth via the social media platforms and discussed in detail how the social media campaign could help in fighting against it via the distribution of various counter-extremist information sources and tools. Thirdly, the problems and limitations of the project were discussed, where matters such as the difficulty on recognizing the sources of factors enabling the causes of radicalism or criticism towards effectiveness of the use of positive counter-radical messages have been mentioned. Fourthly, the paper draws lessons from this project for the Central Asian region in terms of its importance, relevance and applicability in different contextual environments. In conclusion, this paper showed on the one hand the vulnerability of the social media to the influence of radical ideas and ideologies, but also on the other hand the potential of the social media as a tool to counter the radical movements and protect the youth from social marginalization, risk of radical recruitments and manipulation.

Key words: radicalism; social media, Kyrgyzstan, youth, Central Asia.

\author{
Кумар Ерназар \\ Қазақстан Республикасы Президентінің жанындағы Мемлекеттік басқару академиясының \\ Дипломатия институты, Қазақстан, Нұр-Сұлтан к. \\ e-mail: yernazar.kumar@nu.edu.kz \\ Қырғызстандағы жастардың әлеуметтік медиа арқылы дерадикализациясы \\ және оның Орталық Азияға салдары
}

Бұл жұмыста 2016-2017 жылдар аралығында басталған Search for Common Ground Ұйымы жүргізген пилоттық жобаға қарап, Қырғызстандағы радикалды экстремизмге қарсы күрестегі әлеуметтік медианың рөлі талданады. Пилоттық жоба жастардың санасын көтеру мақсатында жүргізілді, жалдаудың радикалды тәуекелдері мәселелері бойынша және радикализм проблемалары туралы қоғамдық пікірталас үшін әлеуметтік медиа алаң құру.

Біріншіден, газет Кеңес Одағы ыдырағаннан кейін Қырғызстан мен Орталық Азиядағы радикализм проблемаларының пайда болу көздері мен себептерін таныстырды. Мұнда ұлтшылдықтың, діни надандықтың және зайырлы нанымдардың үшбұрышты көтерілуі білім беру жүйесінің эрозиясымен және идеологиялық вакуум мәселесімен бірге талқыланды. Мұның бәрі жастардың және жалпы қоғамның әлеуметтік маргиналдануына әкелді. Екіншіден, біз террористер мен радикалды ағымдардың жастарды әлеуметтік медиа платформалары арқылы нысанаға алуының себептерін талдап, әртүрлі экстремистік ақпарат көздері мен құралдарды тарату арқылы әлеуметтік медиа науқанының оған қарсы күресте қалай көмектесетінін егжей-тегжейлі талқыладық. Үшіншіден, жобаның проблемалары мен шектеулері талқыланды, мұнда радикализмнің себептерін тудыратын факторлардың көздерін танудың қиындығы немесе позитивті радикалды хабарламаларды қолданудың тиімділігіне қатысты сындар айтылды. Төртіншіден, газет Орталық Азия аймағы үшін пилоттық жобалардың маңыздылығы, өзектілігі және әртүрлі контекстік ортада қолданылуы тұрғысынан осы жобадан сабақ алады.

Қорытындылай келе атап өтуге тиіспіз, аталған мақалада бір жағынан радикалды идея мен идеологияға әлеуметтік желілердің осалдығын, екінші жағынан, жастарды әлеуметтік маргинализация мен радикалды әрекеттерден қорғауға қарсы құрал ретіндегі әлеуметтік желілердің әлеуетін көрсетеді.

Түйін сөздер: радикализм, әлеуметтік медиа, Қырғызстан, жас адамдар, Орталық Азия. 


\author{
Кумар Ерназар \\ Институт дипломатии Академии государственного управления при Президенте \\ Республики Казахстан, Казахстан, г. Нур-Султан \\ e-mail: yernazar.kumar@nu.edu.kz \\ Дерадикализация молодежи в Кыргызстане через социальные сети \\ и ее последствия для Центральной Азии
}

\begin{abstract}
В данной статье анализируется роль социальных сетей в борьбе с радикальным экстремизмом в Кыргызстане на примере пилотного проекта организации Search for Common Ground, который был инициирован с 2016 по 2017 год. Пилотный проект был направлен на молодежное население с целью повышения осведомленности о рисках радикальной вербовки и создания социальной медиаплатформы для публичного дискурса о проблемах радикализма. Во-первых, в статье представлены источники и причины возникновения проблем радикализма в Кыргызстане и Центральной Азии после распада Советского Союза. Здесь наряду с эрозией системы образования и проблемой идеологического вакуума обсуждался треугольный рост национализма, религиозного невежества и секуляристских убеждений. Все это в конечном итоге привело к социальной маргинализации молодежи и общества в целом. Во-вторых, мы проанализировали причины, по которым террористы и радикальные движения нацеливались на молодежь через социальные медиаплатформы, и подробно обсудили, как кампания в социальных сетях может помочь в борьбе с ней через распространение различных источников и инструментов контрэкстремистской информации. В-третьих, обсуждались проблемы и ограничения проекта, где упоминались такие вопросы, как трудность распознавания источников факторов, способствующих возникновению причин радикализма, или критика эффективности использования позитивных контррадикальных сообщений. В-четвертых, в статье извлекаются уроки из этого проекта для центральноазиатского региона с точки зрения важности, актуальности и применимости пилотных проектов в различных контекстуальных средах. В заключение следует отметить, что данная статья показала, с одной стороны, уязвимость социальных сетей к влиянию радикальных идей и идеологий, а с другой - потенциал социальных сетей как инструмента противодействия радикальным движениям и защиты молодежи от социальной маргинализации, риска радикальной вербовки и манипулирования.
\end{abstract}

Ключевые слова: радикализм; социальные медиа, Кыргызстан, молодежь, Центральная Азия.

\section{Introduction}

The US Department of State and the Bureau of Counterterrorism financed the project named «Social Media for De-radicalization in Kyrgyzstan: A Model for Central Asia» that was implemented by the Search for Common Ground Organization (SCG) for the time period between September 2016 until October 2017 (Jailobaeva \& Asilbekova, 2017: 6). This pilot project has served the purpose to raise the awareness of recruitment risks in preventing and countering violent extremism among the Kyrgyz youth population via the social media outlets (Karimova \& Baktygulov, 2019: 2). It was also initiated in order to tackle the problem of radicalization in a more «softer» way than conventional «hard» methods.

According to its project proposal, its goal was also to provide for young participants per online social media channels a platform for expressing personal grievances and initiating public discourses through promotion of positively related contents (Jailobaeva \& Asilbekova, 2017: 6).

Until the year of 2016, social media was not considered as a tool for de-radicalization policies (Karimova \& Baktygulov, 2019: 4). But with the supportive statement made by the heading figure of the Kyrgyz People's Assembly in October 2016, the message was conveyed not only to the public but also reached NGO's in taking an active stance and opened up their way for funding (Karimova \& Baktygulov, 2019: 4).

\section{Literature review}

Kyrgyzstan has been plagued since its days of independence with numerous religious and ethnic tensions. Alongside that, more than one-third of the population lives under the UN poverty line, where unemployment issues became another challenge to be addressed (Karimova \& Baktygulov, 2019: 3). It is also argued that after the collapse of the Soviet Union, the educational system itself was eroding and affected the youth culture in such a way that the ability to «critical thinking» was simply lost (Karimova \& Baktygulov, 2019: 4). Here, the loss of the previous Soviet educational system meant that there was a vacuum in educational values, as education has a multipurpose role in educating citizens in terms of showing them what is good and bad; perpetrating them the importance of hard work; informing them about the upholding of individual and societal civic rights; and integrating them into the local, national as well as global marketplace. Considering that atheism during the times of the Soviet 
Union played a restricting role with a secularist belief, with the fall of the Soviet Union it meant that people were just freed from their shackles to freely discuss religion on the state level (Shiva, 2016: 11). Extremists often used this momentum to use religion as a mean to establish an alternative political identity that threatened as a result the state's legitimacy (Shiva, 2016: 11). Of course, the secularism movement might not be the only factor bringing the youth to be at risk of radical recruitment, but it is rather the combination of all factors considered.

With a triangular rise of nationalism, religious ignorance and secularist beliefs rising, it brought a boiling pot of different religious streams creating an unstable form of political identity (Shiva, 2016: 11 and 12). A disengaged youth was plagued by social marginalization and stratification within a society where socio-ethnic tensions generated secularreligious schisms. And, eventually all that dismantled youth's hope for a better future and trust in the government (Shiva, 2016: 12). Besides these factors, another factor that could also played a massive role in the rise of ethnic and religious tensions was the economic state itself after the collapse of the Soviet Union, since there was no doubt that the early, mid and late 1990's were tough periods for post-soviet countries, who also had to deal with the issues of economic transition and settling down within the era of globalization and the polarization of the political order around the world.

The problem of radicalization of the youth in Kyrgyzstan through social media outlets is a big concern. Social media being used as an instrumental tool to attract new recruiters is not only a threat to the national security, societal well-being and civic societies establishment, but also for the development of the young Kyrgyz population as it comprises a big chunk of the population.

According to the study done by UNPBF funded project «Youth as Agents of Peace and Stability in Kyrgyzstan» that targeted the youth by looking at the rate of the likelihood for fifteen risky localities to be influenced by radical beliefs due to societal disconnectedness issue, they found out that institutions like the primary or secondary education need to be more strongly engaged with the youth in order to rebuild the broken path between the traditional family values to basic moral education (Levy, Jamankulov \& Sartbay, 2019: 2). Without any direct involvement of parents as well as teachers it is not possible to «morally» protect the youth from being exposed to violence and despair on social media (Levy, Jamankulov, \& Sartbay, 2019). Of course, here comes the question of how well and with which effective methods do primary and secondary educational institutions teach the young people. After all, these institutions form the basis of the society and the mentality of the young people. Furthermore, the topic about de-radicalization problem is very complex and a one-fit approach might not be a panacea for it, but at least a way to reach out to the young people and informing them.

Radicals as well as terrorists strike exactly at the comprehensive problems that the youth face with socio-economic problems, lack of social cohesion in the society and with the politicization issue of religious beliefs as a means to a radical end. According to a local human rights activist an appropriate religious education to young people is an effective instrument in reducing the likelihood of a recruitment process (Sultanov, 2018: para. 6). It was argued that educating the society on the basis of human rights and building upon ideas of solving issues at a peaceful manner is good way to reach out with a vocal tone to the youth (Sultanov, 2018: para. 8).

\section{Research methodology}

For this paper, we will apply a qualitative discourse analysis approach in order to analyze the project named «Social Media for De-radicalization in Kyrgyzstan: A Model for Central Asia» implemented by the Search for Common Ground Organization. The aim of this paper is to thoroughly analyze the aforementioned project from different aspects. These aspects concern the project's contextual importance, its relevance for Kyrgyzstan, their implementation problems and what kind of lessons we can draw from this project for the entire Central Asian region in combatting issues of radicalism and terrorism. Hence, this paper should serve the purpose to enlighten scholars and experts in the field of national security matters or Central Asian region as a whole to understand the importance and relevance of NGO projects as well as their weight in helping to combat such sensitive security matters.

All materials were extracted from only official secondary sources of information. In this regard, the paper analyzes only existing sources of information that were provided on the Internet. These for instance include officially published reports, brochures or journal articles.

The paper is divided into four sections. The first section discusses the problem statement, which this project aims to tackle in Kyrgyzstan. In the second section the role of the social media in the project is analyzed. Following that, the problems and limitations of the project are discussed in a detailed 
manner. Lastly, a section is dedicated to the lessons that we can draw from this project for the Central Asian region.

\section{Results and discussion}

\section{The Role of Social Media for the Project}

According to the project leaders, social media was and still is nowadays the most effective way to spread positive narrative of counter-extremist information (Sultanov, 2017: para. 9). While probably this might be the true for the $21^{\text {st }}$ century, where the Internet and social media have taken over the way how information is transmitted, received and digested, we should though not forget that other sources of information retrieval and transmission can be done via non-cyber ways such as institutional or ideological propaganda. The project itself was split into three stages of firstly a preparatory stage, secondly a research stage and finally a development and launch stage for social media campaigns (Sikorskay \& Baktygulov, 2017: 5). It relied on fifty young Kyrgyz people to reach out awareness campaigns in eight communities, which were heavily affected by the radicalization with their social media movements the target audience (Karimova \& Baktygulov, 2019: 5). By receiving grants by the NGO, these fifty young Kyrgyz citizens were able to conduct independently various social media campaigns through usages of mobile apps and social webs (Jailobaeva \& Asilbekova, 2017: 6). The project evaluation report and surveying the target group of young Kyrgyz participants revealed that social media outlets such as Facebook, Instagram, VK or YouTube were primarily used to get sources about radicalism (Jailobaeva \& Asilbekova, 2017: 25).

An Advisory Working Group was formed that comprised of state officials, social media professionals and religious clerks who helped the young project leaders in social media campaigns, seminars and fields of research for the project in their assigned community to conduct properly the outreach campaign (Sikorskay \& Baktygulov, 2017: 5). This advisory body was especially needed for implementation purposes and training of fifty young leaders (Sikorskay \& Baktygulov, 2017: 5).

Based on survey findings at the end of the project, at the stage of media campaign launch about twenty-nine infographics and three videos in three different languages of Kyrgyz, Russian and Uzbek were produced (Search for Common Ground Organization, 2016: para. 2). These info-graphs addressed not radical issues by depicting them with negative connotations, but rather showed positive and peaceful sides of Islam with verses of Quran and by exposing young viewers with heartwarming phrases to crucial values linked to positive family relationships (Search for Common Ground Organization, 2016a). This way, instead of trying to instill negative associations and emotions about Islam, the project aimed to not eradicate the issue from its roots but fight evil with the good instead of fighting evil with the evil. In this regard the method was not to persuade but to educate the young person. This method should «prevent» the young to become manipulated and give him an understanding of what the religion of Islam in reality is as well as how the message can be tainted for the sake of manipulating people for recruitment purposes. Moreover, with the application of SMM tools, they were able to see which ones had the most views, likes and commentaries on the videos (Sikorskay \& Baktygulov, 2017: 7). In the process of creating videos, it was essential to create not just positive narrative, but effective ways to depict the tragic hero as accurately as possible with his own subjective feelings, thoughts and viewpoint (Search for Common Ground Organization, 2016a).

In one of the videos titled as "Construction", they were able to produce the story following a character of a working migrant who has conflicting thoughts about radical ideas and was unsure of how to properly reset his thoughts into the right path (Search for Common Ground Organization, 2016a: section on «Constaction»). He asks himself whether to follow those «radical» teachings and is often stuck with questioning his existence and meaning of life (Search for Common Ground Organization, 2016a: section on "Constaction»). Though he has time to make a decision on his own, the recruiter always tries to pressure him to give in to be induced to these radical beliefs and not to have second thoughts about leaving (Search for Common Ground Organization, 2016a: section on «Constaction»).

Other projects from SCG also helped to integrate different communities together that have struggled with the rise of radicalism movements. The Jashtan Project in Kyrgyzstan addressed similar issues of radicalism in twenty-seven localities with the involvement of the youth in leadership programs (Sultanov, 2017a: para. 2) (Sultanov, 2018a: para. 1 and 2). This project helped to conduct start-up businesses in cities such as Min-Kush and Saruu, which have facilitated in opening youth centers to self-organize discussions in funding communitybased social projects (Sultanov, 2018a: para. 5 and 8). Thus, mitigating factors that caused radicalism among the youth to prosper and spread. 
Such factors were the following: identity crisis, deficiencies in self-development programs and lack of communication skills with the elderly population (Sultanov, 2017a: para. 8)

\section{Problems and Limitations of the Project}

One of the main limitations of the project was the difficulty to recognize the sources of factors enabling causes of radicalism. While some said it was the combination of nexus between poverty and socio-economic problems leading to recruitment, others said it was the religious illiteracy (Sultanov, 2017a: para. 13). The comprehensive nature of multiple factors and reasons why the young are so susceptible to radical information on the social media outlets also shows us the different ways on how the young people can be recruited. In this case, it is worth saying that even if the young and vulnerable segment of the population does to a certain degree understand the dangers and risks of what radicalism or extremism is as well as is able to use critical thinking to differentiate the good from evil, there is no hundred percent guarantee that they will likely not be continuing to be understanding of that very fact till they become adults. Often, there is a chance that the young people will become somehow remotivated to follow and listen the radical messages and beliefs after they turn adults. Hence, one must be aware of these little risks and the future projects should put their maximum effort and resources to capitalize on their goals in order to get the maximum out of the results not only for their project outcome, but also for the overall benefit of the society and the target group.

The focus on women as target audience has been neglected in this project, especially in relationship to religion (Jailobaeva \& Asilbekova, 2017: 34 and 35). If we take into consideration also the factor that more people will become more engaged with the Internet and the social web or have become already actively engaged since then, then the importance of such projects will grow over time. It was also argued that this is particularly crucial for children transferring from primary schools to secondary education needs not to be overlooked by future research studies of NGO's (Jailobaeva \& Asilbekova, 2017: 34).

The feedback from the final evaluation reports about the project revealed that future studies should take into consideration for social media campaigns the specificities of social media outlet users in terms of their gender, age or level of education and affiliation to religion (Jailobaeva \& Asilbekova, 2017: 34). From my own point of view, this should also help to understand deeper the susceptibility rate of the young people according to socio-demographic variables. This could prove to be especially useful in acquiring rich and first-hand knowledge about an under-researched group of segments of the young people. Another key criticism was that info-graphs or positive messages through videos did not always directly relate to the people in terms of their meanings, and often the youth itself did not understand and were not able to differentiate between concepts such as «extremism» from «terrorism» (Jailobaeva \& Asilbekova, 2017: 35). This problem was especially evident with translations from Kyrgyz to Uzbek language in videos, as the meanings were lost in the process due to lack of cultural adaption (Jailobaeva \& Asilbekova, 2017: 35).

The duration of the pilot project was thought to be rather short and could have been extended for several more months (Jailobaeva \& Asilbekova, 2017: 35). But once again, the pilot project had its time period set firmly and sticking to it showed that the project managed to get results that it desired. Moreover, considering that a fixed amount of financial support was provided would also mean that a result-based approach was prioritized. With that said, results had to be rather effective, accurate and managed on a timely basis. While time constraints might have to a certain degree played as an additional factor for how much information and how deeply analytical the project could delve into the problem matter, prioritizing for getting accurate results and its effectiveness was the right choice. Last but not the least, with the lack of religious leaders' involvement in the project overall, the project lacked a role model in delivering basic teachings of Islam in seminars for participants (Jailobaeva \& Asilbekova, 2017: 34 and 35 ). This aspect probably could have been given more importance overall in terms of re-enlightening the young people by giving them the chance understand that religious leaders exist and get help if needed. After all, the role of the leader is to «lead» people or in other words also «guide» them towards the right path. Without a leader, people would not be given clarifications and justifications for their good or bad deeds. Having a leader by your side, which is especially crucial for young people, a person has a role model to follow and look up for. And as long as this role model shows good qualities of properly leading people towards the right and virtuous path, be it in terms of religious faith or in professional life aspects, the young people will become more confident and be able to differentiate for themselves the good from the bad. 


\section{Lessons Drawing for Central Asia}

Given the counter-extremism social media campaign initiated in Kyrgyzstan in countries like Tajikistan, Kazakhstan or Turkmenistan in the future, it is likely that their web accessibilities might have restrictions for both project initiators and participants. Thus, the pilot project would not be entirely viable in such countries.

However, it is worth taking note that SCG also created a toolkit for application of the project elsewhere with step-by-step process explanations. The toolkit recommends for further action research studies in social media and to work with target audience at a grassroot level (Sikorskay \& Baktygulov, 2017: 24). Creation of an online platform for reports and promotion and distribution of positive narrative should be supported by project initiators (Sikorskay \& Baktygulov, 2017: 24). This is helpful in establishing social networks for upcoming projects in opening start-ups or independent activist groups (Sikorskay \& Baktygulov, 2017: 24). Last but not the least, organizing seminars or trainings to increase Internet and religious literacy with the help of volunteers, religious clerics and social activists is an essential ingredient to take into consideration (Sikorskay \& Baktygulov, 2017: 24).

It is also important to understand that such pilot projects need to culturally adapt original practices from Kyrgyzstan to the local context of other Central Asian states. For instance, making sure that effective media campaigns have crisp, short and clear delivery of messages (Jailobaeva \& Asilbekova, 2017: 35). While only small grants were provided for youth participants of the project, it is recommended to increase the share of grants in the future to have a stronger campaign outreach and involve active young people in a unique project, with which they could help not only their compatriots but also do something good for their country (Jailobaeva \& Asilbekova, 2017: 35). OSCE also recommends strengthening rights of national minorities and to uphold principles of human rights in order to build trust among the participants for online and offline practices (Peter, 2017).

Overall, a more comprehensive approach needs to be developed for upcoming projects that operate on both offline and online tasks with a greater financial support and durational stage. Considering that the coronavirus situation in the whole country has somewhat limited the offline activities of NGOs in fighting against extremist ideological risks, there is also a need for new ideas on how NGOs now should conduct their research on an online format.
This would of course pose a huge challenge for both the society and NGOs in terms of adapting to the new realities, but also positively influence the way that such projects could be approached from a different angle in an unforeseen circumstance like the spread of the COVID-19 pandemic. Central Asia should always be aware of the fact that it has inherited the Soviet mentality, political characteristics of its system and shares historical ties with it over the last several centuries, and some still live being hunted by the Soviet past with lasting issues of identity building processes and various socio-economic matters. Hence, it is worth saying that one cannot run away from the past but may face it and move on with the best intent to change for the better.

\section{Conclusion}

To conclude, by conducting an action research focused project that targeted the youth in specific communities, Kyrgyzstan was able to pioneer as the first country to use social media as a tool to fight radicalism via the help of an NGO. Given the local context of Kyrgyzstan and its specificity of communities, such projects by the NGO would need customization to other regional states context to serve the same purposes in helping the youth and other group of people to become resilient against extremist ideologies, their content and propaganda.

One of the main barriers to the de-radicalization program was the culture itself among the youth. The lack of identity issue was prevalent with bipolar influences of secularism and politicization issue of Islamic religion (Karimova \& Baktygulov, 2019: 4). Apolitical behavior and lack of trust towards the government also undermined the grassroots initiatives of preventive measures at the community level. Here, it is crucial to understand that the context of where people live and the communities as well as local government's level of political commitment towards de-radicalization initiatives also matter. Besides these barriers, sources of recruitment risks have been identified through the project, such as the weak educational system and lack of economic incentives for the young population. As a result, leaving them vulnerable to look for alternatives by searching for the meaning of life in ways that they start easily believing in destructive ideological propaganda. It is though by no means the fault of the people for being deceived or falling into these destructive paths of dogmas, but something that could have been prevented if the right preventive measures were used and implemented on time. Concerning that, I would also add the aspect that 
often certain de-radicalization efforts might work for some communities, while they might not work for certain other communities. This should be taken into consideration and analyzed thoroughly before launching any large-scale NGO-related projects.

In terms of the Kyrgyz government fighting through hard measures the radical recruitment movements and identifying them on the social web, they relied more on reactive rather than preventive mechanisms. This is exactly what has been addressed with this project, and in the future preventive measures should be given more political clout and attention by the public, government and international organizations. Often fighting fire with fire might ignite the problem even more and enflame like a time-ticking bomb. Hence, taking preventive measures are tools that rather educate and not directly remove the risk completely, as the social media along with the Internet has a huge pool of various types of different information that can be both good and bad. This project has helped the young people to understand that they are not alone and can build a strong community to withstand «together» instead of fighting it all by themselves with their own ways.
In the same analogy, the Kyrgyz media itself also pinched the government on how to differentiate between hate-loaded discourses that have a detrimental impact from emotional comments and freedom of expression (Alkanova, 2018: para. 1). Since we speak of pluralistic viewpoints where our project aimed to promote to provide a public discourse for expressing «grievances» of the Kyrgyz youth, it is important to understand such differentiations more thoroughly. The same was also true for differentiation between «appropriate» and «inappropriate» nationalistic public discourse as it can be used as a pretext for terrorists (Alkanova, 2018: para. 9). Others have called upon deficiencies of a legislative basis for using the infamous «Article 299» in Kyrgyzstan for the purpose of bringing people to court for hatredand nationalistic-driven comments on the Internet (Alkanova, 2018: para. 11).

In a nutshell, this project proved to be effective in its own way. It had a target audience that it focused on and had a well-thought out blueprint and program on how to operationalize this pilot project. On top of that, an Advisory Working Group had been created to help fifteen young members of the pilot project to conduct and realize the outreach social media campaign.

\section{References}

Alkanova, E. (2018). How social media users in Kyrgyzstan are turned into «extremists «. Open Democracy, 12 July 2018. Retrieved from: https://www.opendemocracy.net/en/odr/how-social-media-users-in-kyrgyzstan-are-turned-into-extremists/

Jailobaeva, K. \& Asilbekova, G. (2017). Social Media for Deradicalization in Kyrgyzstan: A model for Central Asia. Final project evaluation. Search for Common Ground, 2017. Retrieved from: https://www.sfcg.org/wp-content/uploads/2017/12/KGZ007_Evaluation_Report_Final_Nov_2017.pdf

Karimova, M. \& Baktygulov, S. (2019). Making Deradicalization Work: Case Study - Kyrgyzstan. Search for Common Ground, 2019. Retrieved from: https://prevention.kg/wp-content/uploads/2019/05/Case-study_PCVE_HQ-edited_Mirgul-finalized.pdf

Levy, D., Jamankulov, K. \& Sartbay, T. (2019). Final Report - Project Evaluation: \#Jashstan2: Youth as Agents of Peace and Stability in Kyrgyzstan. Conflict Assessment and Baseline Report. UN Organization, January 2019. Retrieved from: https://www.un.org/ peacebuilding/sites/www.un.org.peacebuilding/files/documents/kyrgyzstan_2018_project_evaluation_eng_0.pdf

Peter, R. N. (2017). Countering Violent Extremism and Radicalization that Lead to Terrorism: Ideas, Recommendations, and Good Practices from the OSCE region. Organization for Security and Co-operation in Europe, 29 September 2017. Retrieved from: https:// www.osce.org/chairmanship/346841

Search for Common Ground Organization. (2016). Social Media for De-radicalization in Kyrgyzstan: A Model for Central Asia. Search for Common Ground, 2016. Retrieved from: https://www.sfeg.org/wp-content/uploads/2016/11/Social-Media-for-Deradicalization-in-Kyrgyzstan-A-Model-for-Central-Asia.png

Search for Common Ground Organization. (2016a). Concept of the professional media campaign. Search for Common Ground, 2016. Retrieved from: https://www.sfcg.org/wp-content/uploads/2016/11/Concept-of-the-Professional-Media-Campaign.png

Shiva, K. D. (2016). Internal Reflective After-Action Review. Reducing Violent Religious Extremism and Preventing Conflict in Kyrgyzstan and Central Asia 2013-2016. Search for Common Ground, 2016. Retrieved from: https://www.sfcg.org/wp-content/ uploads/2017/02/CSSF_KGZ501-Review_Final_Report_13052016.pdf

Sikorskaya, I. \& Baktygulov, S. (2017). Social Media to P/CVE: Toolkit for Practitioners. Search for Common Ground, 2017. Retrieved from: https://www.sfcg.org/wp-content/uploads/2018/01/KGZ-TOOLKIT_Final.pdf

Sultanov, A. (2017). Kyrgyz NGO fights extremism by using social media. Caravanserai, 14 April 2017. Retrieved from: http:// central.asia-news.com/en_GB/articles/cnmi_ca/features/2017/04/14/feature-01

Sultanov, A. (2017a). UN Project to help Kyrgyzstan prevent youth radicalism. Caravanserai, 09 October 2017. Retrieved from: http://central.asia-news.com/en_GB/articles/cnmi_ca/features/2017/10/09/feature-01?mobi_exp=true 
Sultanov, A. (2018). Kyrgyzstan sees success in combatting youth radicalization. Caravanserai, 05 February 2018. Retrieved from: http://central.asia-news.com/en_GB/articles/cnmi_ca/features/2018/02/05/feature-01?mobi_exp=true

Sultanov, A. (2018a). Jashstan project challenges Kyrgyz youth to become more community focused. Caravanserai, 08 February 2018. Retrieved from: http://central.asia-news.com/en_GB/articles/cnmi_ca/features/2018/02/08/feature-01 